\title{
THE MAKING OF BRITAIN
}

\section{The Dark Ages}




\section{THE MAKING OF BRITAIN}

\section{The Dark Ages}

edited by

Lesley M. Smith

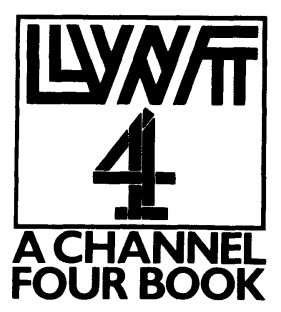

Macmillan Education 


\title{
To Mary and John Smith
}

\author{
(C) London Weekend Television 1984
}

All rights reserved. No reproduction, copy or transmission of this publication may be made without written permission.

No paragraph of this publication may be reproduced, copied or transmitted save with written permission or in accordance with the provisions of the Copyright Act 1956 (as amended).

Any person who does any unauthorised act in relation to this publication may be liable to criminal prosecution and civil claims for damages.

First published 1984

Published by

Higher and Further Education Division

MACMILLAN PUBLISHERS LTD

Houndmills, Basingstoke, Hampshire RG21 2XS

and London

Companies and representatives

throughout the world

Typeset and designed by Columns of Reading

British Library Cataloguing in Publication Data

The Making of Britain.

The Dark Ages.

1. Great Britain - History

I. Smith, Lesley

941 DA30

ISBN 978-0-333-37514-3

ISBN 978-1-349-17650-2 (eBook)

DOI 10.1007/978-1-349-17650-2 


\section{Contents}

List of Maps and Illustrations

vii

Acknowledgements

ix

Preface

Introduction

Lesley M. Smith

1 A Continent in Ferment Philip Dixon

2 After the Romans

Malcolm Todd

3 The Anglo-Saxon Migrations

Richard Hodges

4 The Emergence of Anglo-Saxon Kingdoms

Patrick Wormald

5 Picts, Scots and Britons

Wendy Davies

6 The Christian Connection

Liam de Paor

7 The Viking Nation

Klavs Randsborg

8 The Vikings in Britain

Alfred P. Smyth

9 One English Nation

Pauline Stafford 
10 The Kingdom of the Scots

A.A.M. Duncan

11 Myths of the Dark Ages

Janet L. Nelson

12 The Feudal Kingdoms of Europe Philip Dixon

Notes

173

Notes on Contributors 185

Index 


\section{Irist of MIaps and Illustrations}

1. The Western and Eastern Roman Empires

2. The route of the Goths to the Roman Empire

3. The Forum at Rome

4. The Villa Tivoli

5. The distribution of barbarian tribes outside the Empire

6. A typical German settlement

7. Barbarian grave goods

8. Barbarian metalwork

9. The threats to the Roman province of Britain 22

10. Chedworth Roman Villa 24

11. Mosaic from Lullingstone Roman Villa 25

12. A mosaic depicting Christ, from Hinton St Mary 26

13. The threefold threat to the Western Roman Empire 28

14. Reconstruction of Wroxeter, early fourth-century example of a Roman town

15. The baths at Bath

16. Trade between German barbarians and the Rhine provinces

17. Roman glassware from a barbarian burial

18. The Nydam Ship

19. Carved ship prow

20. Anglo-Saxon settlement in Sussex

21. The reconstructed Anglo-Saxon village at West Stow, Suffolk

22. Anglo-Saxon grave goods from Winterbourne Gunner

23. The kingdoms of Britain c.597

24. The Anglo-Saxon kingdoms c.825 51

25. Offa's gold dinar 
26. Offa's silver penny

27, 28, 29. Treasures from the Sutton Hoo ship burial

30. The distribution of royal vills known from pre-conquest sources

31. Charter of King Aethelbald 'Rex Britanniae' 61

32. The distribution of languages in Celtic Britain 66

33. The Ivybridge Stone 67

34. The Irish migration to Scotland 68

35. The British kingdoms 69

36. The fortress of Dunadd 71

37, 38. Legal records copied into the Lichfeld Gospels 73

39. Pictish symbol stone 74

40. Tintagel 79

41. The evangelisation of Ireland 79

42. Skelling Rock 81

43. Skelling Monastery 81

44. Iona 83

45. Celtic crosses on Iona 86

46. A page from the Book of Lindisfarne 89

47. The Ruthwell Cross $\quad 89$

48. Viking trade routes 92

49. The Gokstad ship 93

50. The fortified wall and harbour at Birka 96

51. Ornate cup from Jelling 97

52. The Jelling Stone 99

53. Jelling 99

54. The Trelleborg Fortress 100

55. Viking raiders 104

56. The Viking invasion of Britain 106

57. Silver penny of S Edmund 111

58. Viking tombs from York Minster 112

59. Stone depicting a snake pit 112

$60,61,62,63$. Silver pennies of Cnut, Guthrum,

Gothfrithsson and Eric Bloodaxe 113

64. 'One King under one God' 118

65. Silver penny showing Edgar as king 119

66. Document showing Edgar as king 119

67. The division of England on Watling Street 121

68. Stone Anglo-Scandinavian tombs 121

69. The King with his ealdormen 123

70. Edgar flanked by his archbishops 128

71. The peoples of Scotland 130

72. The Aberlemno Kirkyard Stone 132

73. A Scottish kinglist 133 
74. Hilltop sites

75. Sueno's Stone

76. A page from the Book of Kells

77. A page from the Book of Deer

78. Queen Victoria and Prince Albert depicted as a Saxon king and queen in the Mausoleum, Frogmore

79. Victorian representation of Alfred inciting his troops to victory

80. Manuscript showing peasants at work

81. Manuscript showing nobles feasting

82. Manuscript showing the condition of women in AngloSaxon Britain

83. Alfred's contribution to British naval development: a Victorian view

84. Silver penny of Alfred

85. The Frankish Empire

86. Model of the palace complex at Aachen

87. Charlemagne

88. The Viking invasion of Normandy

89. Mounted soldiers

90. King Canute

91. William's army at Hastings

The publishers wish to acknowledge the following illustration sources:

Barnaby's Picture Library 3, 4, 10, 15, 91; Mr Ray Gardiner 25, 26, 57, 60, 61, 62, 63, 65, 84; The Schleswig-Holstein Landesmuseum 7, 8, 18; Bridgeman Art Library 11; Trustees of the British Museum 12, 19, 27, 28, 29, 55; The Castle Museum, Shrewsbury 14; The Danish National Museum 17, 51, 52, 53; West Stow Anglo-Saxon Village Trust 21; Salisbury and South Wiltshire Museum 22; The Lodonek Press 33; Mr Mick Sharp 36, 40; The Dean and Chapter of Lichfield Cathedral 37, 38; Anna and Graham Ritchie 39; The Office of Public Works, Dublin 42, 43; Mr Ian Fisher 44, 45; Janet and Colin Bord 47; Oslo University Museum of Antiquities 49; Dr Bjorn Ambrosiani 50; Mr T. Balslev 54; Mr S. Croad 58; The Werner Forman Archive 59; The British Library 46, 64, 66, 69, 70, 80, 81, 82; Mr Peter Saabor 68; The Mansell Collection 89; Trinity College Library, Dublin 76; The Lord Chamberlain's Office 78; The Department of the Environment 75, 79.

The publishers wish to state that every effort has been made to trace all the copyright holders but if any have been inadvertently overlooked they will be pleased to make the necessary arrangement at the first opportunity. 


\section{Preface}

This book is based on the television series The Making of Britain made by London Weekend Television for Channel Four. I am very grateful for all the help I received from those at London Weekend Television who developed and produced the series - Barry Cox, David Tereshchuk, David Coulter and Mike Flood Page. My thanks are due also to the individual contributors who shared with me their knowledge and enthusiasm for the subject, and saved me from errors of interpretation both in the book and in the series. A number of other scholars in the fields of archaeology and early medieval history also advised me and I should like to thank in particular Bertil Almgren, Nicholas Brooks, James Campbell, Tania Dickinson, David Dumville, Simon Keynes, Peter Salway and Martin Welch. Sarah Mahaffy proved a sympathetic and most helpful editor, especially in the later stages of editing. Finally, Debbie Hall, Pam Wilkinson and Jane Crush typed a difficult manuscript with great patience. 